\title{
Humanity Consideration From the Perspective of Money Worship
}

\author{
Jian Tao \\ School of Foreign Languages, Xichang University, Xichang, Sichuan 615000, China \\ "Corresponding author.Email: taojianwin@163.com
}

\begin{abstract}
Japanese famous author Kouyou Ozaki 's famous work "Golden Yasha" [1] deeply considers the distortion of human nature from the perspective of money worship, analyzes the protagonist's variables at the crossroads between rich and poor, and reveals the intricate relationship among love, marriage, life, career and money worship touch the soul core of human nature. Under money worship, due to the distortion of human nature, the narration loses the true happiness and the sadness of the lack of happiness. Even today and even in the future, this is still a difficult problem of human nature.
\end{abstract}

Keywords: kouyou Ozaki; "Golden Yasha"; money worship; Distorted humanity

\section{INTRODUCTION}

Literary master kouyou Ozaki (1867-1903), formerly known as Tokutaro, was a prolific writer. He loves literature. The works tended to be both romantic and tragic, such as the famous work "The Erotic Confession of Two Bichuni" (1889) "Agarwood Pillow" "Two Wifes" "Three Wifes" and "The Girl Next Door" "Golden Yasha" (1897-1903) [2] etc. He became an influential Japanese literary master. In addition to novels, he is also quite original in prose and haiku. "Golden Yasha" serialized in "Yomiuri Shimbun" had a huge impact. The work vividly depicts the miserable intersection of money and love when they inevitably meet. The protagonist Guan Yi and A Gong, the couple's farewell to Atami hot springs and statues, are already famous overseas tourist sceneries. The work is centered on the issues of beauty, love, and money. It depicts the ukiyo-e of the upper and lower social figures with gorgeous words and sincere spoken dialogues. It is one of the most-read works in the Meiji era novels. Kouyou Ozaki had not completed stomach cancer, so he died early at the age of 36 . The continuation of the manuscript was completed by his disciple Oguri Maple according to the concept of his "Memorandum of the Golden Yasha"[2]. "Golden Yasha" was adapted into dramas and movies, and became a "national novel" of the "love textbook" that became so popular in the Meiji era. Its influence lasts for a long time. As far as the comparison of Eastern and Western similar literary works is concerned, Marquez 's famous book "Love in the Cholera Period" in the West is hailed by the media as "The Love Encyclopedia of Our Time" and "Love Textbook". Next, it describes a protracted love lasting more than half a century. In addition, the book is similar to the topic selection of the novel "Wuthering Heights".

\section{ORGANIZATION OF THE TEXT}

\subsection{Variable Balance Weight}

The narrative core of the novel "Golden Yasha": a pair of engaged young men and women who had the appearance of respecting and respecting each other and had a vow to each other. When the rich man Toyama broke in, they had a marriage change and a series of sudden numbers. The fiancee decided to marry a wealthy man under the profound influence of money worship. He has an "overseas background, a villa, an international trading company, a servant, and a maid "[3]... After she married him, she became a lady and was able to hang around in society. In the upper circle, interacting with people with heads and faces, eating, wearing, using, and playing are all expensive and luxury that ordinary people can hardly enjoy; contrary to the situation here is her former fiance, who is not only in great pain, but also in tears, sad Desperate, he even wanted to kill his fiancee[4]. After repeatedly persuading the fiancee to be useless, he had to leave in a sad mood. Driven by the influence of money-richism overnight, he dropped out of school and "became a loan shark" [3].. When people face the crossroads of huge gold or wealth, the consideration of human nature variables is really revealed. Under the influence of money worship, the fiancee who once sworn under the auspices of the world would abandon him without regard to the strong feelings of the unmarried. He paranoidly believes that money and wealth are above everything else, and absolute supremacy, it is under the strong influence of this soul-distorting money worship, even the college preparatory course he is studying has abandoned. The core idea of the writer's finishing touch "Golden yaksha" refers to the "monster of money" that makes normal people betray their beliefs and go astray."Golden Yasha" first describes the relationship 
between the beauty, the rich and the poor. The main characters include the beauty of Fuzawa Palace, the rich and the rich, and the poor students. The beginning of the story is that the beautiful Miya Kuzawa and the college preparatory students have always been in love with each other, and the mountain alliance has sworn in love. She has agreed to be his fiancee. Coincidentally, once she "saw the diamond ring on the finger of the banker's son and was suddenly captured by money."[1] The main characters include the beauty Miya Kuzawa, the rich and the rich, and the poor students. The beginning of the story is that the beautiful Miya Kuzawa and the college preparatory students have always been in love with each other, and the mountain alliance has sworn in love. She has agreed to be his fiancee. Coincidentally, once When the rich man Toyama issued a marriage contract request to Xuzawa Palace through a matchmaker, facing this could change her destiny and Opportunity of family background, the beautiful Miya Kuzawa has long been lurking in the inner marriage balance. It is not so much that the beautiful woman Miya Kuzawafeels poor and loves, it is their family's expectation of this opportunity. Perhaps, some people say that some beautiful women in reality marry ordinary people who do not have villas and no international trading companies. This may exist; but in reality, there are many people who have married women and have international trading companies. After being abandoned for a long time, he was extremely grieved and angry, so he decided to abandon his studies to become a usury accomplice, turning himself into a "money yaksha" to achieve revenge on his fiancee and society. Here we need to add a background: In the "Golden Yasha", the writer described the beauty of Miya Kuzawawith a special style and very delicate pen and ink, knowing that she is unusually beautiful, and beauty is a pass to marry a giant. The tycoon selection criteria of the rich man Toyama is beauty. Poor people even though they once had sweet childhood friendship and mutual respect and love with the beauties of Miya Kuzawa, but they were vulnerable to the strong force of the invaders, rich and rich, and the once vows of the Shanmeng League had become a mirage! Kouyou Ozaki's ability to observe and narrate is very strong, and the character and behavior of the characters are abnormally thorough. For example, when the orphans who lived in the home of the beautiful Kanazawa Palace were desperate, and weepingly begged the beautiful Kanazawa Palace not to think of the poor and love the rich to climb high branches and marry the rich and rich, Wei $\mathrm{Ji}$, his actions were completely futile; The family of Xuzawa Palace said lightly: It's easy to talk. The father of the beautiful Miya Kuzawa also promised a short promise to "send him to study in Europe". In fact, if this story is put on today, how many beauties and families can stick to the mountain alliance pledge? Nowadays, the standard of male selection is to have a sense of security and to be able to give standards such as happiness!

\subsection{Views From Different Positions and Perspectives}

"Golden Yasha" at least describes the different positions and perspectives of the beauty, the rich and the poor: first, the position and perspective represented by the beautiful Miya Kuzawa and its family; second, the perspective of the consistency between the poor Standpoints; third, standpoints represented by the rich man Toyama. In fact, the standpoint represented by the beautiful Miya Kuzawa and its family believes that if Miya Kuzawa marries a rich man, Fu Shanwei continues to enter the rich family, his decentness and sense of security are far greater than the consistency between marrying the poor. At that time, his identity was always poor and helpless, he was the adopted son of the family of Fuze. He is helpless, just a college prep student. Fuze's parents felt it was much better to marry her to Toyama Yuki. And what kind of real world is the depth of the soul of Miya Kuzawaas a beauty? Although the work has a long time span, similar situations can be reproduced. For example, domestic and foreign cases such as "sports car measuring beauty" and "multi-gold measuring beauty" can detect the will of beautiful women: a man met a man on the street (Even consecutive $\mathrm{N}$ places) young, beautiful, and sexy beauties, when men greeted her, she seemed irrational, even a disgusted, contemptuous expression, she said "I have a date with my boyfriend" "I have a boyfriend" and so on, but after the man turned and drove the sports car over or illuminated the huge amount of money, the money worshiper saw immediately and said modestly, "Is this sports car yours? I'm sorry just now." The man said, "Please money The woman went swimming in the sea ... "At the invitation of a private contract, the beauty smiled like a flower and completely agreed; the man asked:" Did you just say that you have a date with your boyfriend, do you have a boyfriend? Let's go together, what about your boyfriend? " "Beauty replied:" I don't have a boyfriend, I was just talking about playing, "or the beauty said:" My boyfriend is a former one and has broken up. "After seeing the process of measuring these beauties, the conclusion is self-evident. This conclusion is that the beauty has an inner world that is too poor to love the rich. To take another example, in a high-end marriage matchmaking meeting held by a high-end marriage agency, the beautician beauties required the man 's net worth to be 50 million, 100 million, or even several hundred million, saying that he was worth the price. Although things have changed, similarities continue to appear, reflecting complex and profound human nature choices. In fact, in reality, the number of beauties that women hope to choose when they marry, but can really get their wish to get married to the "big rich" is, after all, a minority, and the vast majority of money worshipping women's values go to extremes, using improper means such as sugar daddy, recognition of godfather, Be adopted, etc. become derogatory female money tags! Beauty has a strong charm, even irresistible. It is as attractive as a strong magnetic field. This is an eternal theme that exists objectively. The beauty fashion show that 
overflows on the cover of domestic and foreign magazines, a variety of beauty contests, fashion model shows, auto show models Shows, graphic model shows, live beauty shows, etc. are simply dizzy. If the monologue from the heart of the beauty: Anyway, they are married, why not marry a rich one? I hope to change my destiny through marriage, maximize the benefits, be rich in the economy, and have a full sense of security. "I would rather cry in a BMW car than laugh on a bicycle." As for Miya Kuzawa and the coherent green plums and horses, the pure fairy-tale pure love of the mountain alliance pledge disappears in the face of the cruel, poor and rich reality The shadow is missing. The consistent position and perspective of the poor people think that this class-solidified world is extremely unfair: he hated the beauty of Miya Kuzawa even though he was too poor and loves the rich and watery, and said that it will change; at the same time, he hates the parents of Miya Kuzawa For money and wealth, he denied his marriage contract with Miya Kuzawa. There is equivalence in human-to-human communication and cooperation. In other words, it should be called complementary advantages. From the perspective of a man's perspective, the conclusion to the beauty is: money worship, vanity, only money, no real love. The men longed for ideal romantic works similar to the famous female writer Qiong Yao, hoping to meet the pure, rich and beautiful innocent lady. As a rich second-generation boy, like other men, he will only find a woman who is loyal to herself and likes her. At most, it is just a plaything for a commercial woman. The so-called Gold Digger is a woman who blindly worships money, regards the value of money as the highest value, and all values must be subject to the ideas and behaviors of money value. In fact, it should be in two directions: extreme and betraying traditional moral etiquette! Everyone in the world is inseparable from money, but their personal recognition and grasp are different. Some people say that money is not a panacea, but it is impossible to do without money. There is a feeling of antinomy. Money worship is a unique ideological and moral concept of money supremacy, that money is not only almighty, but also a standard to measure all behaviors. With the unique ideological and moral ideas of money supremacy, money is God. The so-called Gold Digger, this term is often used to ridicule and belittle those beautiful women who value money too much. In theory, no one does not want to lead a wealthy and good life, money is not guilty? People who worship money also have the right to fight for their own happiness. Controversy-square view: Anyone is eligible for wealth. Material woman: Advocating money, because this is an era where you can't live without money, but more advocating spiritual enjoyment, using material as the motivation for your struggle, and enjoying life with the money you earn. In fact, the three major marriage items in the 21 st century are: a house, a car, a ticket, a money-laden woman has the ideal and goal of money-laundering, a beautiful woman is her capital, and she is qualified for pride and money-laundering.? Why shouldn't you get true love? True love is not exclusive to Cinderella. Everyone yearns for a better life. Opposite view: marriage based on money is immoral. -A marriage that is not based on feelings is immoral after all. When a woman compares herself to a luxury car. Will someone really love her? When people are equal to money, how is it different from commodities? Money worship is a direct expression of true temperament, which allows them to digitize money and physical feelings. Not everything can be bought with money. Life is not much happy, compared to crying in a BMW, I am still willing to laugh behind the bike. Greedy extravagantly begging the other party to use money to nourish their empty heart.

Is the materialistic society becoming the only way to pursue equality? The answer is no, it will only make you lost.

Money worshiper: There is only money in his eyes. Spending money is unrestrained. He is greedy for vanity. He can do everything to get money.

\subsection{Eternal Theme}

In the end, Kan Ichi Hazama and Miya Kuzawa finally understood: "The most sincere love is not fooled by money, and cannot be exchanged for anything." The beautiful Miya Kuzawa marries into the rich and wealthy Toyama with her youth and beauty. Her identity is a "rich woman". She enjoys the extremely rich material. On the one hand, she appears to be relaxed and leisurely, not doing things, not worrying about eating, wearing, using and playing, seemingly makes the extravagant life envied by outsiders, on the other hand, she appears very emptiness, self-blame, contradiction and entanglement in the spirit, or deep inside. As Milan Kundera portrayed the "unbearable lightness of life" state of mind: she ruthlessly abandoned the real consistency that she really loved her, and even gave her everything, forcing him to become a "golden yasha" in order to get money. "Going to be hospitalized as a loan shark accomplice. Consistently distorted humanity and lost personality. He later got a lot of ill-gotten wealth: when his loan shark owner, Usury boss and his wife, were set on fire, the son of the boss was an upright and kind scholar, and he decided not to use the money shark illicit money left by his father. Boss son gives up property Let Kan Ichi Hazama inherit, and advise him to "Make it a legitimate business"![1] However, as soon as the unwillingness to get rid of this ill-gotten wealth, he took it harder to release the water (loan usury), which hurt many people and forced them to go nowhere ... It has consistently covered up decent private houses with money obtained from others, and achieved the so-called "wealth" with evil behavior. And the dramatic thing is that the beautiful woman Shizawa Palace, who had dumped his fiancee, came to him regardless of the status of "rich woman", and even jealous with his current mistress, "wrestling together."[1] Miya Kuzawa also wrote several letters to Kan Ichi Hazama , hoping to get his forgiveness ... Miya Kuzawa at this time is a beautiful lady who regrets marrying into a wealthy man. The prediction that The prediction that Kan Ichi Hazama once reminded her was later confirmed that the rich man Toyama went back to redeem himself for a geisha 
who maintained an improper relationship with him. Faced with such humiliation, Miya Kuzawa feels reaching the verge of collapse .

\section{CONCLUSION}

The protagonist narrative of Ozaki's famous book "Golden Yasha"-beauty and money worship, even today, the characters from different perspectives and different positions are still controversial. It can be said to be an eternal controversial topic. The protagonist's values of love, marriage, life, occupation, etc. in front of money are variables that are difficult to determine. And it is this kind of indefinable variable that has always touched the deep soul of human nature, leaving the reader with space and aftertaste for further reflection and consideration. This work has similar topics to the story of the famous British book "Whistling Mountain Villa".

\section{REFERENCES}

[1] kouyou Ozaki. "Golden Yasha", Tokyo: Learning Research Institute, 1982, pp. 1-180

[2] Junyang Li. On kouyou Ozaki [J]. Journal of Northwest University (Philosophy and Social Sciences Edition), 1985. pp.83-90.

[3] kouyou Ozaki Written. Yuankan Wu Translated. "Golden Yasha" [M], Chongqing: Chongqing Publishing House, 1983, pp. 1-418

[4] Yukio Miyoshi. "History of Modern Japanese Literature" [M], Tokyo: You Fei Ge, 1975, pp.1-243 (02). pp. 83-90.

[5] Xianshu Quan. The aesthetic connotation of the theme of revenge in "Golden Yasha" [J]. Journal of Dalian Maritime University (Social Science Edition), 2007 (01). pp. 122-124 